Article

\title{
Gender Equality in and on Tibetan Buddhist Nuns' Terms
}

\author{
Padma'tsho (Baimacuo) ${ }^{1}$ and Sarah Jacoby ${ }^{2, * \text { (D) }}$ \\ 1 Philosophy Department, Southwest Minzu University, Chengdu 610041, China; padmatsho@icloud.com \\ 2 Department of Religious Studies, Northwestern University, Evanston, IL 60208, USA \\ * Correspondence: s-jacoby@northwestern.edu
}

Received: 13 September 2020; Accepted: 13 October 2020; Published: 21 October 2020

\begin{abstract}
Gender equality and feminism are often cast as concepts foreign to the Tibetan cultural region, even as scholarship exploring alliances between Buddhism and feminism has grown. Critics of this scholarship contend that it superimposes liberal discourses of freedom, egalitarianism, and human rights onto Asian Buddhist women's lives, without regard for whether/how these accord with women's self-understandings. This article aims to serve as a corrective to this omission by engaging transnational feminist approaches to listen carefully to the rhetoric, aims, and interpretations of a group of Tibetan nuns who are redefining women's activism in and on their own terms. We conclude that their terms are not derivative of foreign or secular liberal rights-based theories, but rather outgrowths of Buddhist principles taking on a new shape in modern Tibet.
\end{abstract}

Keywords: transnational feminism; gender equality; Tibetan nuns; liberal rights

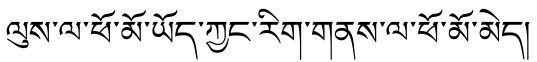

"Even though bodies are sexed, learning is sexless."

-Sherab Zangmo, “Women," Gangkar Lhamo (2013)

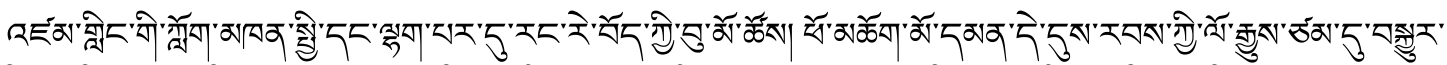

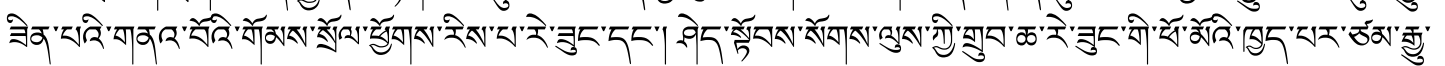

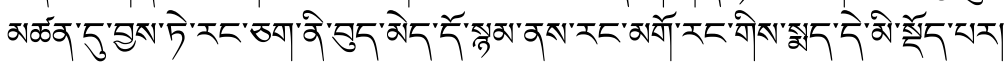

"Our objective is for the global readership in general and for our Tibetan girls in particular not to think "we are women" and consider ourselves inferior on account of differences between men and women that are based on a few biased outdated customs of male superiority and female inferiority, which have been tossed aside as merely bygone history, or based on a few differences in physical strength."

-Larung Gar nuns' preface to the largest Tibetan anthology of Buddhist women's writings,

The Ḍäkin̄̄s' Great Dharma Treasury (2017)

\section{Introduction}

Gender equality and feminism are often cast as concepts foreign to the Tibetan cultural region. This view is sometimes professed by Tibetan monks, such as the 45 -year-old monk Wangchuk who, standing outside of the main monastery hall at Larung Gar Five Sciences Buddhist Academy in eastern Tibet, told an AFP reporter in 2016 that 'The ideas of 'gender equality' and 'feminism' are entirely foreign" (Haas 2016). This viewpoint comes up among nuns as well-in the context of 
the debate over full ordination for Tibetan Buddhist nuns, concepts of gender equality, rights, and feminism have often been characterized as "western secular concerns alien to Asian Buddhist religious communities" (Mrozik 2009, p. 372). In her research on Tibetan nuns, Hanna Havnevik reports being "frequently rebuked by nuns for asking the wrong questions; their concern was spiritual liberation, not opposing inequality inherent in the Buddhist tradition" (Havnevik 2020, p. 273). ${ }^{1}$ Elements of this sentiment are even professed by some proponents of women's empowerment in eastern Tibet who refuse the moniker "feminist," according to research conducted by Hamsa Rajan $(2015,2018)$.

The foreignness of feminism and Buddhism is also emphasized by critics of western liberal feminist overreach, who expose the ways that "feminist Buddhism" and "Buddhist feminism" superimpose liberal discourses of freedom, egalitarianism, and human rights onto Asian Buddhist women's lives, without regard for whether/how these accord with their self-understandings. ${ }^{2}$ The charge is that this results in a reiteration of the imperialist paradigm of "saving brown women from brown men" articulated by Spivak and other postcolonial scholars (Mohanty 1984; Spivak 1988; Chow 1998; Kwok 2002). By privileging white women's perspectives and interpretations on the feminist potentials of Buddhist thought and practice, these studies built on older colonizing logics by positioning western women as the agents of more enlightened forms of Buddhist practice while neglecting the contributions of Asian Buddhist women and rendering their voices mute (Makley 1997; Shneiderman 1999).

Nevertheless, for several decades now, scholars have articulated compelling compatibilities between Buddhist philosophy and feminist theory pertaining to conceptions of personal identity, nonduality, interdependence, and liberation. ${ }^{3}$ Recent additions to this body of work are taking the abovementioned criticisms to heart, rendering "the specter of the secular liberal feminist, unable to conceive of a 'third world' religious woman as agentive or liberated" more of a "straw woman" argument than a reflection of the state of the field (Langenberg 2018, p. 6). In her most recent edited book about Buddhist women titled Buddhist Feminisms and Femininities (2019), Karma Lekshe Tsomo's objectives reflect this evolution of the field through her aims "to investigate the claim that Buddhist feminism is a Western imposition and to examine indigenous Buddhist women's initiatives on their own terms" (p. 18). The latter point is especially important in the context of Tibet where Anglophone words like "feminism" are in fact entirely foreign-Tibetan translations for "feminism" such as bud med ring lugs (literally woman-ism) are neologisms in the Tibetan language that are uncommon in everyday speech. Nevertheless, to conclude from this that the entirety of the purport of "feminism" is foreign to the Tibetan cultural world overlooks the many contributions Tibetan Buddhist women have made and continue to make toward improving the health, wellbeing, educational opportunities, employment, spiritual development, monastic and social status, and safety of their female compatriots in ways that resonate with feminist initiatives. In the Tibetan diaspora, examples include the long-term prominence of the Tibetan Women's Association (TWA) as well as the Women's Empowerment Desk. Tibetan-language women's studies scholarship examining notable women in Tibetan history and analyzing gender discrimination is emerging from Tibet and its diaspora, as are creative works by Tibetan female poets, short story authors, and modern artists. ${ }^{4}$ In religious domains as well, Tibetan

For her monograph based on ethnographic research on Tibetan nuns, see (Havnevik 1989).

The most recent and robust example of this critique is (Salgado 2013).

Notable among these are (Klein 1994, 1995; Gross 1993, 2009; Tsomo 1988, 1999, 2000, 2004, 2012, 2014, 2019; Hu 2011; McWeeny and Butnor 2014). The pinnacle of Salgado's critique (Salgado 2013) as it pertains to Tibetan Buddhist studies is the abovementioned work of Rita Gross. It should be noted, however, that Rita Gross was not trained in Buddhist Studies or Asian languages (her U. of Chicago PhD in History of Religions culminated in 1975 with a dissertation about women in Australian Aboriginal religion). Therefore, Salgado's observation that Gross's work "does not engage contemporary practices of women in the Asian societies she purports to discuss" (p. 29) is both accurate and not representative of the current state of research on women in Buddhism.

4 For just a few examples among the many to choose from, for Tibetan language women's studies scholarship see (Ra se dkon mchog rgya mtsho 2003; Josayma 2017; Chu skyes sgrol ma 2013, 2017) (except the first reference these are authored by Tibetan women). For Tibetan and Bhutanese women's studies research translated into or written in English, see (Chotsho 1997; Madrong and Tsering 1997; Tsomu 2018; Wangmo 2017; Wangmo and Edo 2016). For Chinese-language scholarship on women in Tibetan Buddhism, see (Deji Zhuoma 2003, 2005). For women's contributions to modern Tibetan literature, 
nuns such as those featured in this article are actively working to enhance opportunities for nuns' education, improve the lives of women and girls, and preserve and promote Tibetan women's history. ${ }^{5}$

One way to better understand how Tibetan women conceive of these pro-woman activities is to ask them, engaging in mutually informative dialogue, and then write about these encounters in ways that foreground Tibetan women's voices and interpretations. This article is an attempt to do just this through attentive listening to the oral and written words of a group of Tibetan nuns from the largest Buddhist monastery in the world, Larung Gar Five Sciences Buddhist Academy in the Serta region of Kandzé Tibetan Autonomous Prefecture, Sichuan Province, People's Republic of China (PRC). Larung Gar has emerged as one of the most prominent Tibetan Buddhist centers in the world, educating mass populations of Tibetan monks and nuns, attracting large numbers of Han Chinese and ethnically Tibetan Buddhist devotees, as well as exporting a distinctively Tibetan version of modern Buddhism that has a broad appeal among Chinese-speakers and beyond (Gayley forthcoming). The global speaking tours and publications of Larung Gar's immensely popular and enterprising leading male monastic scholars (khenpos) have garnered the most attention in mainstream media and scholarship alike. In contrast, the large numbers and prominence of nuns have been less visible on the international stage, since Tibetan nuns from Larung Gar have not participated in these international tours and public talks. ${ }^{6}$ Even Jetsunma Mumé Yeshé Tsomo (b. 1966), renowned Larung Gar lama and niece of the academy's founder Khenpo Jikmé Puntsok (1933-2004), has maintained a comparatively low profile, making far fewer public appearances and traveling much less than the well-known Larung Gar khenpos. ${ }^{7}$

That said, the stature of Tibetan nuns at Larung Gar has not gone entirely unnoticed by journalists, who report that Larung Gar nuns are "holding study sessions on feminism and sparking a nascent religious movement" (Haas 2016) as well as "pushing harder for the recognition of their practice to be reflected in equal ecclesiastic status to their male counterparts" (Smith 2016). These characterizations serve as textbook examples of how Tibetan nuns' ambitions and activities get translated into Anglophone liberal feminist discourse about equal rights and resistance that, according to our research, do not accurately reflect the nuns' presentation of their goals, intentions, and ethical values.

Even so, our conversations over several years $(2016-20)^{8}$ with a group of several Tibetan nuns from Larung Gar, as well as our readings of their publications, demonstrate a concerted effort to improve secular and religious women's lives. Though they resist being labeled feminists and certainly do not see themselves as starting a new religious movement, in their words they are actively working to dismantle "the view that men are superior and women are inferior" (pho mchog mo dman gyi lta ba). The Larung Gar nuns we spoke with present women's equality (bud med kyi 'dra mnyam) not in liberal rights-based terms, but rather in distinctively Buddhist terms, denying foreign or secular influences. In this article, we will introduce two forms in which Larung Gar nuns are enacting this Buddhist vision of gender equality: (1) through publishing the first Tibetan-language anthology of Buddhist writings by and about women, and (2) through publishing an annual journal featuring nuns' writing. The following analysis attends carefully to the nuns' oral and written articulations of the significance of these projects, as well as their motivations and inspirations for carrying them out. Reflecting the nuns' words and deeds, we conclude that the nuns' pro-women activities are not derivative of western

see Tibetan references in conclusion. Another rich domain of research on women in Tibet is medicine-among others see (Josayma and Dhondup 1990; Tsering 2005; Chos 'phel and Tshe ring 2008; Fjeld and Hofer 2012).

5 In addition to the work nuns featured in this article are doing to improve nuns' education, see also the Tibetan Nuns Project founded and directed by Richen Khando Choegyal (https://tnp.org).

6 The population of Larung Gar has fluctuated, sometimes reaching above 10,000 residents, more than half of which are nuns.

7 See, for instance, the well-appointed English-language websites of Khenpo Sodargye (http://khenposodargye.org) and Khenpo Tsultrim Lodrö (http://www.luminouswisdom.org), whereas Jetsunma Mumé Yeshé Tsomo maintains much less web presence. Nevertheless, she is deeply revered by the Larung Gar community in general and nuns in particular; for biographies of her see vols. 16 and 50 of (Bla rung ārya tāre'i dpe tshogs rtsom sgrig khang 2017).

8 Prior to this joint work, separately Padma'tsho has been conducting research on Tibetan nuns' education at Larung Gar and elsewhere since 2010. See (Baimacuo [Padma'tsho] 2014). 
or Chinese feminisms, but rather are outgrowths of Buddhist principles taking on a new shape in modern Tibet.

Before we narrate the ways in which our Larung Gar nun interlocutors articulate a Tibetan Buddhist discourse of gender equality, a description of the authorial voices of this article is useful. This research represents a collaborative effort across two countries (China and the U.S.) and two languages (Amdo-dialect Tibetan and English) taken up by two scholars inhabiting different subject positions (one Tibetan woman based in the PRC and one Caucasian woman based in the U.S.), both employed as academics who study Tibetan Buddhism and specialize in women's studies. Bearing in mind "the deeply collective nature of feminist thought" (Mohanty 2003, p. 5), everything written here is the product of an intercultural and multilingual dialogue in which we seek to embody a transnational feminist praxis by carefully listening to each other and to our interlocutors across our national, linguistic, and religious differences (Nagar 2013). Informed by the critiques of Mohanty (1984), Mahmood (2005) and others, we attend to the myriad ways in which the "subjects" of our research, our Tibetan Buddhist nun interlocutors, are agents of women's empowerment as they understand that through a Buddhist hermeneutic, not victims of exploitation by religious fundamentalisms or traditional "third world" gender roles. In order to prevent unwanted scrutiny, we refer to the nuns we interviewed at Larung Gar by their titles, such as "khenmo," meaning "female monastic scholar," and not their personal names, aside from instances in which we are quoting signed published works.

\section{In and on Tibetan Terms}

There are many Tibetan words for feminism, all with different connotations, but all carry a ring of neologism. One can speak of the "equality of the sexes" (pho mo 'dra mnyam), or one can add an "-ism" to that and speak of "the principle of the equality of the sexes" (pho mo 'dra mnyam ring lugs). ${ }^{9}$ One can speak of "women's rights" using the words "women's power" (bud med kyi dbang cha) or "women's status" (bud med kyi thob thang). One can analyze "women's capacities" (bud med kyi nus stobs) and "gender issues" (pho mo'i rten la dbye 'byed). ${ }^{10}$ With the exception of the latter expression, which did not arise during our conversations, the Larung Gar nuns we spoke with were familiar with all of these terms. They did not indicate any familiarity with feminism in Chinese (nüxing zhuyi), or with the main Chinese feminist organization operating in China as a part of the Chinese Communist Party (CCP), the All-China Women's Federation (Zhonghua Quanguo Funü Lianhehui).

When Padma'tsho asked one Tibetan nun at Larung Gar about feminism in Tibetan using the word bud med ring lugs, the nun commented,

Yes, I've heard of that, but I don't know much about it. That is about rejecting the idea that girls cannot do certain things, and cannot finish certain things, so why should they go to school? Everyone thinks about girls this way, but everyone wants boys to go to school and gain knowledge.

A khenmo who Padma'tsho spoke with repeatedly over several years recounted that even though growing up as a nomad girl from a poor family in eastern Tibet she did not have any exposure to American feminist history, through conversations she's had since becoming a nun, she learned enough to wonder:

Before the 1920s, women could not vote [in the U.S.], so they protested. Nowadays, feminism comes from that, but the problems remain. Almost 100 years have passed, and how can this inequality be changed?

9 For the latter definition, see (Goldstein 2001, p. 165).

10 The latter term appears in (Josayma 2017). All of these were the subjects of a rich conversation during the panel titled "What is 'Feminism' in Tibet about?" organized by Nicola Schneider and Hamsa Rajan (at which Padma'tsho presented a paper on aspects of this research) at the 15th International Association of Tibetan Studies Meeting in Paris on 11 July 2019. 
Though the Larung Gar nuns we spoke with knew about feminism when we used Tibetan terms for it, they consistently denied that their objectives were feminist or that their goal was to achieve equality between men and women. For instance, the same khenmo added,

For myself, I don't think about women's and men's equality ('dra mnyam), and also I have never spoken about this; I never thought about it that way in my mind. I don't hold this view.

That said, Khenmo made it clear that she did not appreciate the many ways in which women's lives were harder, with fewer opportunities, than were available to men in the context of rural eastern Tibet (the western regions of Sichuan Province, PRC) in which the two main household occupations are farming and nomadic pastoralism:

As for the idea of male superiority and female inferiority, I am not sure if this is an earlier historical fact or a contemporary social custom, really I don't know. Women are not equal ('dra mnyam). Regarding women's lower status, we can see that in nomad and farmers' areas women are treated like animals. We are not happy about this. Generally this isn't because women aren't loved. It's a habit. However, it is not the fault of the [Tibetan] ethnicity (mi rigs). The view that men are superior and women are inferior is not the fault of Tibetans. If everyone works hard and has self respect and courage, not just Tibetans, but everyone can develop. If this happens, then women's situation will improve- they will not be treated like animals. You and I-everyone in Tibetan areas knows this.

She expressed her discontent with what she perceives as women's lower status in Tibetan society at the same time as she tried to ensure that her remarks would not be interpreted as criticizing Tibetans as an ethnic group. ${ }^{11}$ That she repeatedly offered this defense of Tibetan culture in an interview at which only Tibetan women were present and without any prompting about Tibetan ethnic identity suggests the cultural sensitivity of talking about women's (in)equality.

A year later Padma'tsho had a chance to ask the same khenmo to elaborate about what she meant by saying that women are treated like animals. She explained that it had to do with women having less power (dbang cha chung chung) than men in the household:

In a family with a mother and a father, women don't have power. Men enjoy what the family has-he drives a car, rides a motorcycle, and has fun. Women just work and work at home. If she goes out, she doesn't even have the right to use 100 yuan. ${ }^{12}$ In that situation, there is no way we can call that equal. If there is love between a man and a woman, and they do the same work, respect each other, and the man also helps with the women's work, they both should share the household income and enjoy equal amounts of joy and sorrow.

In each conversation Padma'tsho conducted with this khenmo, she repeatedly proposed a solution to the problem:

But women do a lot of housework. In families, usually the man spends the money and goes around enjoying himself. And the women stay at home like servants. This is not right. If everyone does her own work, then the situation may change. Nowadays many people are talking about equality, saying "women need equality." For me, I never used the words "women's equality" (bu mo'i 'dra mnyam) and also I never think about that. I think the main thing is to do something. No one can say that we are not allowed to do this work, like the proverb "Whatever the subject is, it can be put into practice."13

11 Others have noted the tension between preserving Tibetan national unity and engaging in feminist activism (Rajan 2015, p. 149).

12100 Yuan is less than \$15.00 USD.

13 Khenmo expressed this Tibetan proverb as "kha byang ci yin na lag len zer gyi thub pa." In other words, anything one can talk about, one can put into practice. If you can say it, you can do it, so don't just talk about it—do it! 
The real value is not found in debating about gender equality for Khenmo, but in taking concrete action to improve women's circumstances. She explains:

About gender equality, I don't talk about that. The word is not in my mouth and also not in my heart. I don't have that view. But when I think about how in some families women are like servants, I don't like that. Men think about what they should have; women see themselves as servants. This is their way of thinking. I don't debate about men and women's equality. I don't say, "I need equality." I don't like to debate. What I hope is that all women can enhance their self-confidence, knowledge and learning. Thinking about how to take action is important. I don't like just talk. Nowadays people talk; one person says some things; another says others. This talk has no meaning. We can't listen to this. If you're a Dharma practitioner, then practice! If you're a business person, do business! I think we should take action.

Khenmo is not convinced of the value of theoretical analysis or argument about women's status, and she negated Padma'tsho's inquiry about whether her actions are feminist (bud med ring lugs). First Padma'tsho asked Khenmo if she's ever read books about feminism, and Khenmo replied, "I've never read about that." Khenmo steered the conversation back to her vision of action not talk, in and on her terms:

For all of us, I think the main thing is taking action. If we have done this work, then we don't need to just talk. I never talk about just the words of equality between women and men-I don't like this, it is not right. Taking action is the main point. This is what is important. You used the word feminism (bud med ring lugs). From our view we probably would talk about reducing "the view that men are superior and women inferior" (pho mchog mo dman gyi lta $b a)$ - that is how we would discuss equality.

Here, equality appears as a virtue, yet it is one earned not through debate, but action. This action is not something one woman or one culture is able to achieve alone; it takes a community of women who support and esteem each other for progress to be made. Speaking directly to Padma'tsho, a middle-class Tibetan female professional in China, Khenmo said:

We need to do work about women. And we need to help each other. If we do this, our mutual ability will improve. For instance, if I feel jealousy toward someone like you with higher education and a good situation and I don't help you, that is women's shortfall. Otherwise, if we help each other, then you can do your research and can accomplish something. We can all achieve our respective projects if we help each other.

For me I don't argue about women's status (thob thang). Deep down in my heart, I'm thinking that from the time of the Buddha until now, there has been the issue of male superiority and female inferiority (pho mchog mo dman); I never thought that women were equal. To give an example, take a lama and a nun-if they do exactly the same work, the lama [male Buddhist teacher] will always be praised and the nun will never be because she is a woman (bud med). Even if they do the same work, they don't get the same praise. I have the feeling it's like that. If the lama accomplishes more work than the woman, giving praise to the lama and not the woman is okay. But if they do the same work, just because he is a man and I am a woman, women will also support the man and esteem him and not support the woman. That is damaging for women. Everyone should esteem each other properly. For women from each culture, whoever does beneficial work, all of us should esteem and support each other. Then we can help each other's situation. Most women on the Tibetan plateau work hard for their livelihood. But some work in culture or research women's issues. If we can all help each other, even if we don't have a lot of wealth or capacity, then each of us will have some success; we can help each other gain results. 
The focus of Khenmo's words is how women treat each other; she directs her attention away from men's superiority and toward what women can do for each other, and for themselves, to ameliorate women's inferiority. Khenmo's attention toward what women can do to raise their own inferior social position could be interpreted as an instance of victim blaming (akin to the interpretation of Rajan 2015, p. 142) because she directs her critique in part toward women and not only toward men in hegemonic positions. However, especially coming from a nun who lives surrounded by female peers, we hear Khenmo's words not as victim blaming, but as a call for Tibetan women to collaborate with and support each other as a means to remedy their disadvantages. We also hear dismay coming from the nuns about both laywomen's household work "as servants" and nuns' lack of recognition. Although the nuns we spoke with clearly name these inequities and lament them, they resist labeling their objectives as pushing for women's equality ( $b u$ mo'i 'dra mnyam) because they perceive this as an ideology that accentuates dispute, a theoretical debate that produces only empty talk and no results. Far from being opposed to women's equality, they seek to effect it through their actions. Given that Khenmo and her monastic colleagues are all about action, we turn next to spotlight two signature actions they have taken.

\section{Taking Action by Anthologizing Tibetan Buddhist Women's Lives}

The Tibetan impulse to anthologize religious texts has been pervasive over time. In the broadest sense, anthologizing has deep Buddhist roots that are integral to the development of Tibetan literature itself, for the process of translating and organizing Buddhist scriptures from Indic languages into Tibetan canons generated extensive Tibetan doxographic and literary genre classification systems and terminology. Tibetan religious texts are bundled according to whether they are the Word of the Buddha (bka' 'gyur), or commentaries written by Buddhist disciples (bstan 'gyur); whether they are Buddhist sūtras drawn from Theravada Buddhism, Perfection of Wisdom sūtras drawn from Mahāyāna, or tantras from Vajrayāna; they are bundled as collections of hymns (mgur), advice (zhal dams), prophecy (lung bstan), and visionary experience (nyams snang), among many other organizing principles. Tibetans have extensively published collected works (gsung 'bum) of individual religious masters, the vast majority being male, as well as anthologies of writings by figures in a single religious lineage, such as the Biographies of the Kagyu Masters featuring the founding fathers of the Kagyu School of Tibetan Buddhism, for one example among many (Don brgyud nyi ma 1972-1976). There is even one collection of biographies of female masters all from the Bon religious lineage-Khandro Dechen Wangmo's Biography of the Ocean of Dākinīs (Mkha' 'gro rgya mtsho'i rnam thar), which she produced as revealed scripture (gter ma) in 1918 (Mkha' 'gro bde chen dbang mo 1985). Tibetan anthologizing efforts not only maintained sectarian bounds; one vast counter-example is the Five Great Treasuries (mdzod chen $\operatorname{lng} a$ ), an encyclopedic compilation of teachings from many different religious lineages, including Buddhist history, cosmology, mantra, liturgy, revelation, and more, which Jamgön Kongtrül compiled in the nineteenth century as a way to preserve myriad Buddhist lineages in a non-sectarian (ris med) manner. ${ }^{14}$

Nevertheless, Tibetans had never applied this enthusiasm for anthologizing to the project of collecting Buddhist texts written by or about women until a group of Larung Gar nuns began just this in 2011. ${ }^{15}$ That year seven Tibetan nuns from Larung Gar Five Sciences Buddhist Academy formed an association dedicated to publishing Buddhist women's writings. They named themselves the "Larung Ārya Tāre Book Association Editorial Office" after the Buddhist deity Tārā, who is a prominent bodhisattva of Indian Mahāyāna Buddhism, as well as a female Buddha in Tibetan Vajrayāna Buddhism. The first order of business for the fledgling association was to find Tibetan Buddhist texts written by

14 For a useful overview of Jamgön Kongtrül's massive textual production (100 volumes), see https://www.shambhala.com/ jamgon-kongtrul-readers-guide/.

15 For a fuller account of this project, see (Padma'tsho and Jacoby forthcoming). 
or about women. From the beginning, this was a collective effort and not the possession of a single nun: "We thought of it together; I can't remember who was the first to say it. We've been working on this for a long time." Before setting out they consulted their guru, the nun Jetsunma Mumé Yeshé Tsomo, niece of the founder of Larung Gar Khenpo Jikmé Puntsok. After receiving her sanction, nuns we spoke with repeatedly emphasized that they did this work in their spare time between their other full-time commitments studying Buddhist philosophy and performing rituals and prayers. The work was challenging because finding extant Tibetan manuscripts about women sent them on searches all over the Tibetan region, and because often only one copy of a manuscript could be found, often with archaic or inconsistent spelling, as well as missing sections. Once the nuns did manage to collect texts about women, none of them were yet digitized, requiring the nuns first to teach themselves how to type and use computers, and then to painstakingly type the manuscripts into digital files themselves. In one nun's words:

The textual work was incredibly difficult. We worked for about five years on the Dākinīs' Great Dharma Treasury. First we went all around gathering texts. We went to Lhasa and everywhere we could to find texts. Women's writings were few at that time and were not easy to find. We developed relationships with people with this project in mind and asked very politely for texts, but there were a tiny number of texts by women. When we found some, they were very old. Many of them were not clear and we couldn't understand them. It is such difficult work, and so different from [male] lamas' writing. Lamas' writing and women's writing are different because for lamas' writings, they are published by the Lhasa Publishing House once, by Sichuan Publishing House again, and so forth, so it's much easier to republish them. But women's historical writings are so few. They are almost nonexistent. So we had to start anew, from "a, b, c." We had to enter them newly into the computer. For the Dēkinīs' Great Dharma Treasury, we had a group of people who all worked hard. It was very difficult. It wasn't my goal alone. All of us wanted to help women and publish women's writing together. We entered it all in from the beginning and edited it. But for lamas' books, there are many source texts (ma dpe); for women we don't have many; we just found one here, one there.

After years of this work, in 2013 the Ārya Tāre Book Association published their first 16-volume anthology of women's writings titled Garland of White Lotuses: the Biographies of the Great Female Masters of India and Tibet (Bla rung ārya tāre'i dpe tshogs rtsom sgrig khang 2013). These volumes were the product of a searching and inputting process that the nuns carried out completely independently, with no financial support from other parts of Larung Gar or the Chinese government. After this initial publication, other prominent male monastic scholars (khenpos) from Larung Gar learned of the nuns' work, and offered to support them. With these additional funds, the nuns bought more computers in 2014 and 2015 and expanded their operation. By 2018, the Ārya Tāre Book Association was formally incorporated into the Education branch (Slob ston khang) of Larung Gar, and its staff expanded to 11 nuns. ${ }^{16}$ During this phase they continued their text collection, typing, and editing efforts, and the initial volumes grew. In 2017, they published a new beautifully printed hard-cover 53-volume anthology of Buddhist women's writings called Ḍakinīs' Great Dharma Treasury (Bla rung ārya tāre'i dpe tshogs rtsom sgrig khang 2017). Whereas the first 16-volume edition contains mainly biographical accounts of Indian and Tibetan Buddhist women, the 53-volume version is divided into four parts: (1) volumes 1-18 are biographies of Indian, Tibetan, and Chinese Buddhist women; (2) volumes 19-49 are collected works of Tibetan female masters and assorted religious teachings; (3) volume 50 is a collection of praise texts for female deities and human masters; (4) volumes 51-52

16 The Education Branch (Slob ston khang) is the section of Larung Gar Five Sciences Buddhist Academy that manages the education system, the teaching of courses at Larung Gar, and handles affairs related to publications. 
are advice collections for women written by assorted male masters, followed by the final volume, 53, which is the preface and the table of contents for the entire anthology.

Both the initial 16-volume series and the larger 53-volume version include a preface written by the editors of the Ārya Tāre Book Association, which we have translated in full (in Padma'tsho and Jacoby forthcoming). Here, we quote just one paragraph of their preface (Bla rung ārya tāre'i dpe tshogs rtsom sgrig pa 2017) that outlines their objectives for this massive and unprecedented project:

Our main objectives are first and foremost to protect and promote the writings of the female scholar adepts who have come before in India and Tibet, which are like the principal wealth of the world. Secondly, our objective is for the global readership in general and for our Tibetan girls in particular not to think "we are women" and consider ourselves inferior on account of differences between men and women that are based on a few biased outdated customs of male superiority and female inferiority, which have been tossed aside as merely bygone history, or based on a few differences in physical strength. Additionally, to serve as examples of what types of undertakings one should accomplish in both this life and future lives, our main objective is to provide learning materials that reinforce ways of correctly knowing which endeavors to accept and reject, as well as reinforce how externally one should conduct oneself virtuously in accordance with the present conditions and internally one should have courage and strength along with intelligence. We have published, distributed, and promoted this priceless collection as medicine to nourish the wellbeing and happiness of the world in general, and in particular as a gift for female Dharma practitioners of the Snow Land [of Tibet], who are its great stewards. (pp. 3-4)

The nuns felt the need to protect and promote women's writings in particular since there were so few manuscript copies of women's writings, and those that existed were scattered across Tibet and its diaspora, making it a real possibility that they could disappear. In one khenmo's words, "If we don't put them together now, in the future they will be gone." The second point they make is the written version of what they repeatedly said orally to us about "the view of male superiority and female inferiority." It is impossible to mistake how they feel about this view-it is a "biased and outdated custom" that has been "tossed aside as mere bygone history." And if it has not, their preface seems to suggest, the extensive record of almost two hundred illustrious women's lives and religious teachings that follows this preface will surely further that tossing out process.

The third point made in the preface articulates what we may call a type of "morality of exemplars," drawing on Caroline Humphrey's terminology, in which morality is presented not in abstract codes of behavior but through particular models for how to live a virtuous life (Humphrey 1997). The nuns feel a sense of responsibility to future generations to share these female models of exemplary accomplishment. As they express this in their preface,

So that future generations of Tibetan mothers and daughters will know about the outstanding tradition of excellent mothers ${ }^{17}$ of the Snow Land of Tibet, and so that their conduct will not contradict the essence of holy divine Dharma and secular ethics as appropriate for their era, we think that it is extremely important to recognize that the responsibility falls on our shoulders to take steps to improve their circumstances. (p. 2)

A crucial way of doing this according to the nuns we spoke with is to leave a tangible record of past women's deeds, advice, and teachings, which they have accomplished with their 2017 publication. One khenmo explained to Padma'tsho after she asked where the idea came from to publish these volumes:

17 Here, the Larung Gar nuns are using "mothers" metaphorically to refer not only to biological mothers, but also to notable historical Tibetan women in general. 
Tibetans or any other ethnicity need some results that future people can see from history (lo rgyus). Men and women's value is different. Through reading history we can see men's value. We should also be able to show the real value of women's contribution to Tibetan culture. If women make history, then their value will be visible to other Tibetans.

It was clear to the nuns as they traveled around Tibet searching for women's writings that the value of women's contributions to Tibetan history and religion was often not appreciated by those they encountered:

Especially when we asked about women, people didn't want to help. They would mention that there is a text, but they wouldn't help us find it. There are many people like that, with different opinions. When we asked about women, some wouldn't even answer our questions.

The nuns' last point in the quoted preface passage above states that they have published, distributed, and promoted their collections of Buddhist women's writings for the world in general, as well as for female Tibetan Buddhist practitioners, who are "the great stewards of the Snow Land." A khenmo told us that they printed one thousand copies of the 53-volume set and then began distributing them:

We gave them to people who help women and who do research about women's writing. We sent the books to libraries and universities in this country [PRC] and foreign countries for scholars. We weren't selective, saying we should send them to one person but not another-we gave them out without sectarian bias because the volumes themselves are non-sectarian.

We can vouch for the truth of the nuns' far-reaching generosity in sending their volumes to researchers and libraries around the world; one day in 2018, Sarah Jacoby returned to her home in Chicago to find two large cartons on her doorstep shipped from the PRC containing the entire D. $\bar{a} k i n \bar{\imath} s^{\prime}$ Great Dharma Treasury! The nuns are adamant that these books are meant to help women, and not to turn a profit. With that in mind, they focused on distributing the books to scholars and researchers, including Tibetans, foreigners, monastics and laypeople. A few Chinese people who were Tibetan Buddhist disciples bought the books as well, intending them as a gift for their lama. The nuns opted not to distribute the books in bookstores in Tibetan areas of the PRC or even in Larung Gar's bookstore, because they were not aiming to make money.

In 2018 the Larung Gar nuns we spoke with felt a true sense of accomplishment after the 53-volumes were published. A khenmo instrumental in the process explained why she felt so pleased:

One reason is that for a long time in my mind I wondered if we could finish this work. The work would take a long time, and because it was so difficult, we might not be able to finish it. Now that we've put this out, it's like passing an exam! This is not just oneor two-days' short project. We worried about whether it would be finished. However, we've accomplished our important objective, so I am happy. The second reason is that we encountered some difficulties doing this work. After our hard work, we overcame our difficulties. We really like the volumes because we accomplished our goal.

The nuns in the Ārya Tāre Book Association have the sweet pleasure of seeing their efforts through, and making good on their promise not to just talk, but to enact the change they wish to see in the world.

\section{Taking Action by Publishing a Tibetan Nuns' Journal}

Another important literary production created by a group of Larung Gar nuns is the first Tibetan nuns' journal. The journal is called Gangkar Lhamo (Tib. Gangs dkar lha mo; Chin. Xueshan Tiannu; Eng. Snow Mountain Goddess), and to date it has received no scholarly attention. Though it is not a production of the Ārya Tāre Book Association, its leadership and contributing writers are overlapping with the Ārya Tāre membership, and can be understood as a related cultural phenomenon. The first 
edition of Gangkar Lhamo was published in 2011, and it has been published annually since. From 2011 through 2017, the journal published 130 different articles, all written by Tibetan women, mostly nuns but also a handful of laywomen. Contents are varied, written in both Tibetan poetry and prose, covering subjects including memories of Khenpo Jikmé Puntsok, praise for Jetsunma Mumtso, stories about their hometowns, their mothers, and ideas about Tibetan women's status and future.

From 2011 to 2013, Gangkar Lhamo was edited by just one khenmo. She was in her 40s when Padma'tsho spoke with her. She was born in a rural area and studied Tibetan with her father as a child while helping with pastoral work. At 15 years old, she ordained and joined her home area nunnery. She did a pilgrimage to Lhasa, followed by a three-year retreat. Drawn by the prospect of receiving a religious education, she went to Larung Gar in 1996. Fourteen years later in 2010, she received her Khenmo degree after completing the monastic curriculum of the five major subjects of exoteric Buddhist Studies. ${ }^{18}$

In 2014, some khenpos took note of the fledgling journal and helped its founder set up an association called the Snow Mountain Goddess Editorial Subdivision (Gangs dkar lha mo'i rtsom sgrig tshan chung), which then became a part of the Education branch (Slob ston khang) of Larung Gar. This association includes 6-8 khenmos along with one khenpo. Since 2017, the association gives awards to nuns who've published the best writing in the journal. They publicize new issues of the journal online via WeChat. In its early years, the journal had a print run of 2000 copies annually, printed in Chengdu, Sichuan Province, PRC. The association sold and also gave away copies of their journal to a readership comprised mostly of monks, nuns, and other literate Tibetans. An important source of support for the journal is Jetsunma Mumtso, and her religious poetry can be found in multiple journal issues.

Gangkar Lhamo is intentional about its focus on female writers, decrying their rarity as "stars in the daylight" and underscoring their importance. The preface from the 2015 edition signed "by the editorial subcomittee" reads in full,

Dear readers who are fellow siblings from the three provinces ${ }^{19}$ : In this cool Dharma realm completely surrounded by a garland of white snow mountains, if we examine earlier times, since education standards have improved somewhat since then, these days an inexpressibly huge variety of books in the public and private spheres are produced, like crops that grow in the summertime. Reading them, even though we find them compelling, we are saddened that women's essays have become as rare as stars in the daylight. We think the reason for this is that in the past extremely few Tibetan women took on the responsibility or had the inclination toward studying the sciences of grammar, poetry, and so forth. Until now, not many had the full resources required to diligently study. Education and knowledge are necessary for both men and women; at all times they are certainly needed. Therefore, with the intention of future advancement and uplifting our friends, we must open mindedly pursue our education and writing. In order for our lifetimes to bring about results, we must sincerely work hard. (Rtsom sgrig tshan chung pa 2015, p. 1)

Amid the variety of poetry and essays published in Gangkar Lhamo one can find not only powerfully worded articulations contradicting "the view of male superiority and female inferiority" (pho mchog mo dman kyi lta ba), but also some explicit injunctions for gender equality (pho mo' $i$ 'dra mnyam) and equal rights (thob thang 'dra mnyam). One example of an essay addressing gender equality is "The Way Forward for You and Me" (Nga dang khyed kyi mdun lam) by Rikdzin Chödrön, published in the 2012 issue of Gankar Lhamo. ${ }^{20}$ When Padma'tsho met Khenmo Rikdzin Chödrön in June 2018, she was in

18 The five major subjects of exoteric Buddhist studies ( $g$ zhung chen bka' pod lnga) at Larung Gar include (1) Valid cognition (tshad ma, pramāna), (2) Monastic discipline ('dul ba, vinaya), (3) Abhidharma (mngon pa, abhidharma), (4) Middle way (dbu ma, madhyamaka), and (5) Perfection of Wisdom (phar phyin, prajñāpāramitā).

19 Referring to the three regions of Tibet: Kham, Amdo, and Utsang.

20 Padma'tsho has independently published a complete translation of this work; see (Padma'tsho forthcoming). 
her 40s. She told Padma'tsho about her childhood in the Kongpo region, where she had some secular education prior to joining the nunnery-she studied Tibetan, Chinese, and some math at her village school for three years followed by another three years at her county's elementary school. At the age of fourteen she ordained at Shuksep Nunnery in Central Tibet. She was motivated to go to Larung Gar for further studies, and there received the title of khenmo after completing the monastic curriculum of the five major subjects of exoteric Buddhist Studies. After receiving her degree, Khenmo Rikdzin served as an assistant teacher for several years, before becoming a teacher in her own right. She has now trained about twelve khenmos herself.

In "The Way Forward for You and Me," Khenmo Rikdzin emphasizes gender equality (pho mo 'dra mnyam) and women's rights (bud med kyi thob thang) in such a way that initially sounds analogous to Euro-American liberal feminist discourse, but then takes on a Tibetan Buddhist twist. She begins with the claim that "our rights (thob thang) should be equal to that of men. In my view, "equality" ('dra mnyam) means whatever activities men are able to do, women should also be allowed to do them and thereby have the same opportunities as men" (Rikdzin 2012, p. 13). In Khenmo Rikdzin's observation, Tibetan women, whether they be laywomen or nuns, do not enjoy this equality now:

Laywomen don't have control over themselves; against their will they are bound with rope and married off. Many are sold into marriage or sent as brides to enemies for the purpose of settling disputes. In particular, the way people view monks and nuns is different. Toward a monk, everyone respects him and views him as an object of veneration. No matter how educated, good intentioned, and dedicated to benefitting others a nun is, not only do people not perceive her good qualities, but instead think that she shaved her head because she was unable to support herself by working in the secular world. These are the major faults of our [Tibetan] ethnicity that I want to discuss. (Rikdzin 2012, p. 15)

Khenmo Rikdzin unabashedly levies critique on the Tibetan ethnicity as a whole for the inferior social status of women. At the same time, her words are tempered by a resistance to "empty talk" about equal rights that resonates with Ārya Tāre members' comments. She cautions that,

If we want to move in that direction [toward equal rights, 'dra mnyam gyi thob thang], we won't gain anything by debating with uninformed confusion and anger "We want rights. We want gender equality." These are just empty words. (Rikdzin 2012, p. 13)

So, if advocating vociferously for equal rights is not the best approach, how should Tibetan women be thinking about and working toward this goal? Khenmo Rikdzin recasts discourse about gender equality into a larger Tibetan Buddhist worldview:

But we women need to constantly keep this in mind: No matter whether we are laywomen or nuns, being self-interested about our direction and the goal of our own rights is of little importance. Our purpose is not bringing about temporary equality with men. Rather, think that what is truly important is bringing about equality for the general fulfillment of the Buddhist teachings and beings, and for the advancement of the [Tibetan] ethnicity. That is the complete and authentic meaning of our rights (thob thang). (Rikdzin 2012, pp. 16-17)

Khenmo Rikdzin's "equality" is not about self-promotion, not about foreign influence, and not about contradicting the broader altruistic principles of the Buddhist teachings. It is an equality that is implicitly about gender equality (pho mo 'dra mnyam) and is labeled as such elsewhere in the essay, but here lacks the "gender" (pho mo) prefix, rendering it broadly beneficial not only to Tibetans, but also to the "[Buddhist] teachings and beings" (bstan 'gro). By expressing equal rights in this normative Buddhist language of universal compassion, Khenmo Rikdzin is skillfully situating it in Buddhist terms. She reiterates: 
In conclusion, once again my aspiration is for the impact of all women of the Land of Snow Mountains who are benefitting the world in general and our ethnicity in particular not to be erased. Along with making this difficult-to-express aspiration, we must never be mistaken with regard to equality and respect. So that this positive custom will not decline, I am offering this hope-please keep it in mind always. (Rikdzin 2012, pp. 17-18)

Khenmo Rikdzin's [gender] equality is in keeping with respect (gus bkur), as seen by their pairing in this passage, and these are part of a positive custom (ya rabs kyi lugs srol), which could also be translated as a "virtuous tradition." Far from being antithetical to the Buddhist teachings or recently imported from elsewhere, Khenmo Rikdzin underscores the indigenous nature of this positive custom of equality and respect that has been upheld by former generations of women of the Land of Snows. The task at hand is to preserve this impact (literally footprint or imprint, zhabs rjes) so that it will not fall into decline or be erased.

This alignment between tradition, virtue, Buddhist learning, and gender equality is also clearly legible in another powerful essay from Gangkar Lhamo titled "Women" (Skyes ma tsho) written by Sherab Zangmo from the Lhokha region of Central Tibet. Sherab Zangmo's essay is divided into two parts; part one is addressed to "girls" (bu mo tsho), repeated in the vocative with each sentence, referring to female householders who do typical forms of women's work. She addresses part two, also in the vocative, to "nuns" (btsun mo tsho), demarcating them as a separate category of people who are "completely free from the suffering of women" (bud med kyi sdug bsngal mtha' dag las bral). We translate the essay into English for the first time here given its brevity and relevance:

\section{Women}

Sherab Zangmo, from Lhokha Lhungtse

\section{One}

Girls: The fate of my sisters is to expend their precious human birth in the dung enclosure, with the livestock, in the fields and in the house. How is this the only fate you can have?

Girls: Even though it isn't our fate, we have been locked into the trap of this fate.

Girls: By any means we must awaken from this thick sleep of ignorance.

Girls: Like the metaphor of a frog stuck in a well, you are duped, living in a small world, painting your pure face and adorning yourself with jewelry made of various stones. Our precious human life is like a rainbow-there is nothing aside from this.

Girls: Feeling like we need to cast our heads down only because of these things makes no sense.

Girls: It is not the case that we must only herd the livestock and till the fields.

Girls: If we girls are continually surrendering to others' influence, how can we ever be beautiful?

Girls: In this time of the 21st century, how is it okay for us to still hold only the view that men are superior and women are inferior?

Girls: But how is it acceptable for us to only spout empty talk?

Girls: Therefore, starting with us, it goes without saying that we need to diligently study the ten Tibetan arts and sciences.

Girls: We also need altruism and pure intentions; shame and modesty.

Girls: Our ultimate goal must be to magnificently spread the path of white light. 
Nuns: Being completely free of the suffering of women, from the perspective of being people who serve mother sentient beings:

Nuns: Not only must we diligently study the ten Tibetan arts and sciences, but we must journey through the pleasure grove of the academy. ${ }^{21}$

Nuns: We must actually perform practical actions that benefit others, not just talk about doing this.

Nuns: We must speak our own opinion in public and be without bias toward Buddhist doctrine and the authority of the five sciences.

Nuns: Even though bodies are sexed, learning is sexless.

Nuns: With confidence in Machik Labdrön's insight and Nyangtsa Kargyen's courage, we must diligently cultivate gender equality (Sherab Zangmo 2013, pp. 72-73)

Locked in the trap of women's housework, dulled by the thick sleep of ignorance, living in a tiny artificial enclosure like a frog in a well, girls' fate (or destiny, las dbang) is dire without the benefit of education in Tibet's 10 subjects of the arts and sciences, which include the five major fields of knowledge (logic, medicine, visual arts, grammar, and Buddhist dharma) and the five minor subjects (poetics, composition, synonyms, drama, and astrology). ${ }^{22}$ This education is the ticket, according to Sherab Zangmo, for laywomen to break free from entrapment. For nuns, this is also true but even more so. They must not shy away from making their voices heard in public once they are endowed with the richness of learning, for even if bodies appear as male and female, learning (rig gnas) has no sexual differentiation. However, just talk is not enough; practical action that brings about real benefit to others is the priority. Sherab Zangmo draws on no model for her ode to gender equality outside of Tibetan cultural resources, for she finds powerful precedent enough in the combined strength of the famous 11th-century female yoginī Machik Labdrön's religious insight (shes rab) and the worldly cleverness of Milarepa's mother Nyangtsa Kargyen, who ardently defended her children's inheritance rights.

It is impossible to romanticize Tibetan nomadic pastoral life when reading the reflections of Tsultrim Palmo from Dzatö published in Gangkar Lhamo (Tsultrim Palmo 2013). In her essay titled "Don't Disparage the Nomad Girl's Pathway Forward," Tsultrim Palmo speaks in the first person about girls' travails working in animal husbandry:

As for us, trailing after livestock, amid waves of falling snow and roaring icy wind, the years pass by. Experiencing any number of hardships, we nomad girls expend our youth in dung and mud. Never tasting the milk ocean of the five sciences, we never see the beauty of the myriad subjects of learning. With scant opportunity for women to attend school, kind teachers cannot provide any education beyond how to recite the alphabet. (p. 74)

Her advice for her compatriot nomad girls:

Listen! Don't spend your whole life herding livestock—dawn's smiling girl welcomes you onto the long pathway forward to your brilliant shining future. Once you awaken from the stupor of backwardness, she will accompany you on your path of advancement. Study the worthy jewel of scholarship; this is your method in support of discovering your life's value, so please don't forget! (p. 74)

21 Journeying through the pleasure grove of the academy (slob gling gi skyid tshal 'grims dgos) refers to completing the monastic curriculum at Larung Gar.

22 For further analysis on the 10 arts and sciences in Tibet and their particular combination of religious and secular subjects, see (Townsend 2016). 
This strongly worded progress narrative places education as the beacon of future advancement, far from the muddy dung of the pasturelands. Spurred on by the friendly welcome of female companionship on the pathway forward, scholarship is the means through which she will discover her value. This wording is richly resonant with Vajrayāna significance, for what we translate above as "method in support of" is more literally "method companion" (thabs grogs), a word used in esoteric contexts for tantric consort. Here, instead, the nomad girl's method companion is learning itself.

Tsultrim Palmo concludes with a pointed message for nomad girls' parents, revealing the intended recipient of her title's injunction:

Parents of the pasturelands stuck in the ditch of stupor-if your nomad girl yearns for an education, don't be impelled by ignorance to say "that is pointless!" If she wants to attend the local school, don't criticize and insult that goal. This is the long-term way to discover her life's future. Not only that, it is the supreme medicine that dispels the diseases of backwardness and timidity. Do you understand? (p. 75)

Both the exuberance of the nuns' delight at their newfound educational opportunities as well as the ongoing and pervasive obstacles to education that rural Tibetan girls face are palpable in all of these writings from Gangkar Lhamo.

\section{Conclusions}

With Tibetan historical references supporting them, nuns from Larung Gar are reimagining the terms of what womanhood and gender equality mean in the 21st century. For the first time, the category of "woman" is a principle around which editors are organizing Tibetan literary works. Larung Gar nuns are not alone in this phenomenon; there is a parallel emergence of anthologies of secular female-authored works of Tibetan literature. Particularly noteworthy in this regard are the publications put together by Palmo, a professor of Tibetan literature at Northwest Nationalities University in Lanzhou, Gansu Province, PRC. ${ }^{23}$ Several other compilations of female-authored literary works have since emerged from urban areas in the Amdo region of eastern Tibet, not so far from the more rural area in which Larung Gar is situated. ${ }^{24}$

Even though these literary publications indicate a broader centering of women's experiences taking place in 21st-century Tibet, Larung Gar nuns resisted causal explanations for their efforts that point toward local secular domains. The Ārya Tāre members we spoke with also did not understand their vision of cultivating a global sisterhood of Buddhist women as deriving from secular feminist (bud med kyi ring lugs) sources outside of the Tibetan cultural sphere, such as the All-China Women's Federation (Ch. Zhongguo funu lianhe hui) or those based in foreign countries. ${ }^{25}$ As the Larung Gar nuns we spoke with see it, the major influences undergirding the Ārya Tāre Book Association come from Buddhists texts and practices themselves. ${ }^{26}$ In an effort to affirm this, this article has portrayed elements of the rhetoric and logic with which nuns are enfolding gender equality into a Buddhist frame. The aspect of this Buddhist hermeneutic that sounds most strongly in conversation with the nuns is their call to action, instead of what they see as divisive argumentation about women's

23 In (Dpal mo 2005), Palmo published an anthology of women's poetry (Bzho lung, The Milk Pail Hook), followed by a four-volume collection of literary works written by Tibetan women published in (Dpal mo 2011) (Deng rabs bod rigs bud med kyi dpe tshogs, Collection of Contemporary Tibetan Women), followed by another five-volume series (titled Dmangs phan rig mdzod: bud med rtsom pa po'i dpe tshogs, Treasury of Knowledge for the Benefit of the People: A Collection of Women Writers' Works) comprised of single-authored volumes written by Tibetan women in (Dpal mo 2014). For an English-language overview of Palmo's publications and women's health work, see (Robin 2015).

24 For a study on Tibetan women's writings, see (Lcags rdor rgyal and Go shul grags pa 'byung gnas 2017).

25 They did not mention the most well-known international organization cultivating a global sisterhood of Buddhist nuns, Sakyadhita (https://sakyadhita.org).

26 They are not alone in finding resources within Buddhism to correct "the view that men are superior and women are inferior;" see (Holmes-Tagchungdarpa 2019) for other instances in which "Buddhist ideas and practice remained a rich resource for concepts of gender equality" for Buddhist women (p. 167). 
equality. After all, as a khenmo we spoke with pointed out, feminism (in the U.S.) comes from women protesting for suffrage, and still 100 years later how is it that inequality persists? Our Larung Gar nun interlocutors' disinterest in being characterized as feminists who argue for women's equality should not be understood as an acceptance of what they perceive as the lower status of girls, laywomen, and nuns. In both speech and writing, they articulate their dismay that (from their perspectives) parents in rural Tibet do not see the value in educating their daughters, that girls and women work relentlessly at home, literally stuck in the mud and entrapped by the livestock enclosure, unable to go out and spend proceeds from their labor without censure from their husbands. They lament that nuns are not equally recognized for their positive qualities, no matter how educated, virtuous, and altruistic they are. However, they seek to change these "biased outdated customs of male superiority and female inferiority" not by protesting for women's equality in liberal terms, but rather in and on their own terms, which align respect for women with honoring the Buddhist teachings and Tibetan heritage.

To articulate this, they do not rely on a revisionist Buddhist history in which women and men, monks and nuns, enjoyed a perfect social equality, but rather on collecting, compiling, preserving and remembering the wealth of women's history extant in Tibetan records. There they find ample models ranging from the fiercely protective mother of the 11th-century Tibetan yogi Milarepa, Nyangtsa Kargyen, to the great yoginīs of Tibet's distant past such as Yeshé Tsogyel and Machik Labdrön, as well as those within living memory, including Sera Khandro, Do Dasel Wangmo, Dechen Chökyi Wangmo, Taré Lhamo, and many others.

Larung Gar nuns' work plumbing the depths of this archive as well as their own burgeoning skills in commentarial, biographical, and creative writing evidenced in Gangkar Lhamo all stem from their emphasis on education. As such, their work can be understood as a development of the modern Buddhist values implemented at Larung Gar decades earlier by its founder Khenpo Jikmé Puntsok, who initiated and promoted nuns' educational opportunities. Prior to this, the 10 subjects of a complete Tibetan education in the arts and sciences have historically been the preserve of male ecclesiastics and lay government officials. Even the five major subjects of the Buddhist monastic curriculum (gzhung chen $b k a^{\prime}$ pod lnga) have been unavailable to most nuns until recently, as have the advanced monastic degrees of Khenmo and Geshema. ${ }^{27}$ As more nuns and laywomen gain access to monastic education and university training, the extent of Tibetan women's historical and contemporary contributions to Tibetan history, literature, religion, and arts will continue to flourish. As Dechen Yangkyi from Dergé expresses it in her short Gangkar Lhamo piece titled "Girls Growing up in the Snowland", "it is my duty as a young nun to esteem women's rights (bud med kyi thob thang) and the Buddhist teachings and to ardently appeal for this" (Dechen Yangkyi 2013, p. 75). Larung Gar nuns' Dākin̄is' Great Dharma Treasury and Gangkar Lhamo publication projects are just two examples of what nuns can do with an enhanced education, and there are more to come.

Author Contributions: The labor of producing this research was evenly shared between authors. P. took on the main responsibility of interviewing nuns at Larung Gar (due to restrictions prohibiting non-Chinese citizens from entering Larung Gar S.J. was not present during the interviews), after which both authors listened to the recordings of the interviews and translated them together in full. After we discussed the article's contents, S.J. took on the main responsibility of writing up this research in English, while P. edited and fine-tuned the results. Both authors have read and agreed to the published version of the manuscript.

Funding: The authors gratefully acknowledge the funding provided to Padma'tsho, whose research is supported by "the Fundamental Research Funds for the Central Universities", Southwest Minzu University (Grant Number 2020PTJS03005 and the Grant of 16BZJ014). Both authors received the American Academy of Religion's Collaborative International Research Grant for their project titled “The Formation of Female Religious Exemplars in Tibet," which helped make this research possible.

27 For more about Tibetan nuns' education, and specifically about nuns' education at Larung Gar, see (Baimacuo [Padma'tsho] 2015). Just as this article was going to press, Liang and Taylor (2020) published an informative article about Larung Gar's Khenmo program of study. 
Acknowledgments: The authors appreciate the insightful feedback garnered from presenting earlier versions of this research at two different International Association of Tibetan Studies (IATS) Meetings-Sarah Jacoby presented a paper in Bergen, Norway (June 2016) titled "A Garland of White Lotuses: Oral History and Women's History in Contemporary Tibet" on the panel titled "Rethinking 'Oral History' in Tibet" that she co-organized with Charlene Makley and Dasa Pejar-Mortensen. Padma'tsho presented a paper in Paris, France (July 2019), titled "The Meaning of Feminism for Tibetan Women and Nuns" on the panel titled "What is 'Feminism' in Tibet About?" organized by Nicola Schneider and Hamsa Rajan.

Conflicts of Interest: The authors declare no conflict of interest.

\section{References}

Baimacuo [Padma'tsho]. 2014. Courage as Eminence: Tibetan Nuns at Yachen Monastery in Kham. In Eminent Buddhist Women. Edited by Karma Lekshe Tsomo. Albany: State University. of New York Press, pp. 185-94.

Baimacuo [Padma'tsho]. 2015. Dang dai zang zu ni zhong xin jiao yu ti xi de diao cha yan jiu (An Investigation of a New Educational System for Contemporary Tibetan Nuns). Zong Jiao Xue Yan Jiu 3: 176-83.

Bla rung ārya tāre'i dpe tshogs rtsom sgrig khang, ed. 2013. 'Phags bod kyi skyes chen ma dag gi rnam par thar ba pad +ma dkar po'i phreng ba (Garland of White Lotuses: The Biographies of the Great Female Masters of India and Tibet). Lhasa: Bod ljong bod yig dpe rnying dpe skrun khang, vol. 16.

Bla rung ārya tāre'i dpe tshogs rtsom sgrig khang, ed. 2017. Mkha' 'gro'i chos mdzod chen mo (Ḍākinīs' Great Dharma Treasury). Lhasa: Bod ljongs bod yig dpe rnying dpe skrun khang, vol. 53.

Bla rung ārya tāre'i dpe tshogs rtsom sgrig pa. 2017. Sngon 'gro'i gtam (Preface). In Mkha' 'gro'i chos mdzod chen mo'i dkar chag rin chen gser gyi lde mig (Precious Golden Key: Dākin̄̄s' Great Dharma Treasury Table of Contents). Lhasa: Bod ljongs bod yig dpe rnying dpe skrun khang.

Chos 'phel, Nor bu, and bKra shis Tshe ring. 2008. Mnga' ris smad yul skyid grong rgya dgu'i lo rgyus dang brel ba'i skyid grong grwa khang dkar ba'i sman pa mkhas grags can blo bzang sgrol ma'i nang mi'i lo rgyus nor bu'i me long. (A Brief Account of the Famous Tibetan Lady Doctor Lobsang Dolma Khangkar (1935-1989) and her Family, Including Historical Materials on Kyirong, South West Tibet). Dharamsala: Amnye Machen Institute.

Chotsho, Tsering. 1997. A Drop from an Ocean: The Status of Women in Tibetan Society. The Tibet Journal 2: 59-68. Chow, Rey. 1998. Ethics after Idealism: Theory-Culture-Ethnicity-Reading. Bloomington: Indiana University Press.

Chu skyes sgrol ma. 2013. Bod kyi lo rgyus steng gi bud med grags can gyi lo rgyus mdor bsdus (A Brief History of Renowned Women in Tibetan History). Dharamshala: Shes yon lhan tshogs kyi spyi khyab yig tshang.

Chu skyes sgrol ma. 2017. Bod kyi bud med skor glengs ba (A Discussion about Tibetan Women). New Delhi: Ldi li bod khang.

Dechen Yangkyi. 2013. Kha ba gangs can ljongs nas 'tshar longs byung ba'i bud med tsho (Girls Growing up in the Snowland). Gangkar Lhamo 75.

Deji Zhuoma (Bde skyid sgrol ma). 2003. Zangchuan fojiao chujia nüxing yanjiu (A Study of Tibetan Buddhist Nuns). Beijing: Shehui kexue wenxian chubanshe.

Deji Zhuoma (Bde skyid sgrol ma). 2005. Nüxing zai zangchuan fojiao zhong de jiaose yu diwei [The Role and Status of Women in Tibetan Buddhism]. Xizang yanjiu [Tibetan Studies] 4: 41-47.

Don brgyud nyi ma. 1972-1976. Bka' brgyud pa'i skyes chen dam pa rnams kyi rnam thar (Biographies of the Kagyu Masters). TBRC W20499. 4 vols. Palampur: Sungrab nyamso gyunphel parkhang.

Dpal mo, ed. 2005. Bzho lung. Deng rabs bod kyi bud med rtsom pa po'i snyan rtsom gces btus (The Milk Pail Hook. A collection of Poetic Works by Contemporary Women Authors from Tibet). Beijing: Mi rigs dpe skrun khang.

Dpal mo, ed. 2011. Deng rabs bod rigs bud med kyi dpe tshogs (Collection of Contemporary Tibetan Women). Beijing: Krung go'i bod rig pa dpe skrun khang.

Dpal mo, ed. 2014. Dmangs phan rig mdzod. Bud med rtsom pa po'i dpe tshogs (Treasury of Knowledge for the Benefit of the People. Collection of Women Writers). 5 vols. Xining: Mtsho sngon mi rigs dpe skrun khang.

Fjeld, Heidi, and Theresia Hofer. 2012. Women and Gender in Tibetan Medicine. Asian Medicine 6: 175-216. [CrossRef]

Gayley, Holly, ed. forthcoming. Voices from Larung Gar: Shaping Tibetan Buddhism for the Twenty-First Century. Boulder: Snow Lion Press.

Goldstein, Melvyn C. 2001. The New Tibetan-English Dictionary of Modern Tibetan. Berkeley: University of California Press. 
Gross, Rita M. 1993. Buddhism after Patriarchy: A Feminist History, Analysis, and Reconstruction of Buddhism. Albany: SUNY Press.

Gross, Rita M. 2009. A Garland of Feminist Reflections: Forty Years of Religious Exploration. Berkeley: University of California Press.

Haas, Benjamin. 2016. Equal Rites: Tibetan Nuns Seek Matching Status. March 10. Available online: https://news. yahoo.com/equal-rites-tibetan-nuns-seek-matching-status-061654684.html (accessed on 15 February 2020).

Havnevik, Hanna. 1989. Tibetan Buddhist Nuns: History, Cultural Norms, and Social Reality. Oslo: Norwegian University Press.

Havnevik, Hanna. 2020. Traces of Female Voices and Women's Lives in Tibetan Male Sacred Biography. Life Writing 17: 259-76. [CrossRef]

Holmes-Tagchungdarpa, Amy. 2019. New Buddhist Women Across Borders: Buddhist Influences and Interactions in Alternative Histories of Global Feminisms. In Buddhist Feminisms and Femininities. Edited by Karma Lekshe Tsomo. Albany: SUNY Press, pp. 165-78.

Hu, Hsiao-Lan. 2011. This-Worldly Nibbana: A Buddhist-Feminist Social Ethic for Peacemaking in the Global Community. Albany: SUNY Press.

Humphrey, Caroline. 1997. Exemplars and rules: Aspects of the discourse of moralities in Mongolia. In The Ethnography of Moralities. Edited by Signe Howell. London: Routledge.

Josayma, Tashi Tsering. 2017. The Representation of Women in Tibetan Culture-Strengths and Stereotypes. The Tibet Journal 42: 111-41.

Josayma, Tashi Tsering, and K. Dhondup. 1990. Dolma and Dolkar: Mother and Daughter of Tibetan Medicine. Delhi: Yarlung Publications.

Klein, Anne C. 1994. Presence with a difference: Buddhists and feminists on subjectivity. Hypatia 9: 112-30. [CrossRef]

Klein, Anne C. 1995. Meeting the Great Bliss Queen: Buddhists, Feminists, and the Art of the Self. Boston: Beacon Press.

Kwok, Pui-lan. 2002. Unbinding Our Feet: Saving Brown Women and Feminist Religious Discourse. In Postcolonialism, Feminism \& Religious Discourse. Edited by Laura Donaldson and Kwok Pui-lan. New York: Routledge, pp. 62-81.

Langenberg, Amy Paris. 2018. An Imperfect Alliance: Feminism and Contemporary Female Buddhist Monasticisms. Religions 9: 190. [CrossRef]

Lcags rdor rgyal and Go shul grags pa 'byung gnas. 2017. Bud med rtsom pa pos gsar rtsom gleng ba (A Discussion of Modern Literature Authored by Tibetan Women). Zi ling: Mtsho sngon mi rigs dpe skrun khang.

Liang, Jue, and Andrew Taylor. 2020. Tilling the Fields of Merit: The Institutionalization of Feminine Enlightenment in Tibet's First Khenmo Program. Journal of Buddhist Ethics 27: 231-62.

Madrong, Migyur Dorje, and Sonam Tsering. 1997. A Discussion on Some Great Women in Tibetan History. The Tibet Journal 22: 69-90.

Mahmood, Saba. 2005. Politics of Piety: The Islamic Revival and the Feminist Subject. Princeton: Princeton University Press.

Makley, Charlene. 1997. The meaning of liberation: Representations of Tibetan women. The Tibet Journal 22: 4-29.

McWeeny, Jennifer, and Ashby Butnor, eds. 2014. Asian and Feminist Philosophies in Dialogue: Liberating Traditions. New York: Columbia University Press.

Mkha' 'gro bde chen dbang mo. 1985. Mkha' 'gro rgya mtsho'i rnam thar (Biographies of the Ocean of Ḍākinīs). Dolanji: Tibetan Bonpo Monastic Community.

Mohanty, Chandra Talpade. 1984. Under Western eyes: Feminist scholarship and colonial discourses. Boundary 2: 333-58. [CrossRef]

Mohanty, Chandra Talpade. 2003. Feminism without Borders: Decolonizing Theory, Practicing Solidarity. Durham: Duke University Press.

Mrozik, Susanne. 2009. A Robed Revolution: The Contemporary Buddhist Nun's (Bhikṣuni) Movement. Religion Compass 3: 360-78. [CrossRef]

Nagar, Richa. 2013. Storytelling and co-authorship in feminist alliance work: Reflections from a journey. Gender, Place \& Culture 20: 1-18.

Padma'tsho, (Baimacuo), and Sarah Jacoby. forthcoming. Lessons from Buddhist Foremothers. In Voices from Larung Gar: Shaping Tibetan Buddhism for the Twenty-First Century. Edited by Holly Gayley. Boulder: Snow Lion Press. 
Padma'tsho, (Baimacuo). forthcoming. The Way Forward for You and Me. In Voices from Larung Gar: Shaping Tibetan Buddhism for the Twenty-First Century. Edited by Holly Gayley. Boulder: Snow Lion Press.

Ra se dkon mchog rgya mtsho. 2003. Gangs ljongs skyes ma'i lo rgyus spyi bshad (General Explanation on Tibetan Women's History). Lhasa: Bod ljongs mi dmangs dpe skrun khang.

Rajan, Hamsa. 2015. The discourse of Tibetan women's empowerment activists. Revue d'Etudes Tibétaines 33: 127-53.

Rajan, Hamsa. 2018. The ethics of transnational feminist research and activism: An argument for a more comprehensive view. Signs: Journal of Women in Culture and Society 43: 269-300. [CrossRef]

Rikdzin, Chodrön. 2012. Nga dang khyed kyi mdun lam (The Way Forward for You and Me). Gangkar Lhamo, 13-18.

Robin, Françoise. 2015. Caring for Women's Words and Women's Bodies. A Field Note on Palmo and her 'Demoness Welfare Association for Women.' Revue d'Etudes Tibétaines 34: 153-69.

Rtsom sgrig tshan chung pa. 2015. Sngon 'gro'i gtam (Preface). Gangkar Lham 1.

Salgado, Nirmala. 2013. Buddhist Nuns and Gendered Practice: In Search of the Female Renunciant. New York: Oxford University Press.

Sherab Zangmo. 2013. Skyes ma tsho (Women). Gangkar Lhamo, 72-73.

Shneiderman, Sara. 1999. Appropriate Treasure? Reflections on Women, Buddhism, and Cross-Cultural Exchange. In Buddhist Women Across Cultures: Realizations. Edited by Karma Lekshe Tsomo. Albany: SUNY, pp. 221-38.

Smith, Katherine. 2016. Larung Gar Nuns Push for Gender Equality in Tibetan Buddhism. Buddhistdoor Global. March 14. Available online: https://www.buddhistdoor.net/news/larung-gar-nuns-push-for-gender-equalityin-tibetan-buddhism (accessed on 15 February 2020).

Spivak, Gayatri Chakravorty. 1988. Can the Subaltern Speak? In Marxism and the Interpretation of Culture. Edited by Cary Nelson and Lawrence Grossberg. Urbana: University of Illinois Press, pp. 271-313.

Townsend, Dominique. 2016. Buddhism's Worldly Other: Secular Subjects of Tibetan Learning. Himalaya 36: 130-44.

Tsering, Tashi. 2005. Outstanding Women in Tibetan Medicine. In Women in Tibet. Edited by Janet Gyatso and Hanna Havnevik. London: Hurst \& Company, pp. 169-94.

Tsomo, Karma Lekshe, ed. 1988. Sakyadhītā: Daughters of the Buddha. Ithaca: Snow Lion.

Tsomo, Karma Lekshe, ed. 1999. Buddhist Women Across Cultures: Realizations. Albany: SUNY Press.

Tsomo, Karma Lekshe, ed. 2000. Innovative Buddhist Women: Swimming Against the Stream. Richmond: Curzon.

Tsomo, Karma Lekshe, ed. 2004. Buddhist Women and Social Justice: Ideals, Challenges, and Achievements. Albany: SUNY Press.

Tsomo, Karma Lekshe, ed. 2012. Out of the Shadows: Socially Engaged Buddhist Women. New Delhi: Sri Satguru Publications.

Tsomo, Karma Lekshe, ed. 2014. Eminent Buddhist Women. Albany: SUNY Press.

Tsomo, Karma Lekshe, ed. 2019. Buddhist Feminisms and Femininities. Albany: SUNY Press.

Tsomu, Yudru. 2018. Women as Chieftains in Modern Kham History. Inner Asia 20: 107-31. [CrossRef]

Tsultrim Palmo. 2013. Phyugs rdzi bu mo'i mdun lam rlung la ma skur (Don't Disparage the Nomad Girl's Pathway Forward). Gangkar Lhamo, 74-75.

Wangmo, Sonam. 2017. Gendered Roles in Buddhist Religious Practices in Bhutan: A Case Study of Two Nunneries. Ph.D. Thesis, University of Malaya, Kuala Lumpur, Malaysia.

Wangmo, Sonam, and Juli Edo. 2016. Empowerment Through Monastic Education: A Case Study of Buddhist Nuns in Bhutan. SARJANA 31: 29-44.

Publisher's Note: MDPI stays neutral with regard to jurisdictional claims in published maps and institutional affiliations.

(C) 2020 by the authors. Licensee MDPI, Basel, Switzerland. This article is an open access article distributed under the terms and conditions of the Creative Commons Attribution (CC BY) license (http://creativecommons.org/licenses/by/4.0/). 